\section{GEOGRAPHY AND THE HIGHER CITIZENSHIP}

I WAS born in Paradise-fool's paradise it proved to be. I refer to that snug and comfortable world that existed in millions of minds before 1914 that world of peaceful progress in which forces of finance, commerce, common sense, and good will were to prevent any such thing as a world war. We were to have enduring peace while we worked our society along step by step toward better ends.

This paradise of peaceful progress was blown to atoms by the World War.

Will there be other World Wars? Must our children or our children's children be crushed by tanks, blown up by air bombs, made insane or shaking wrecks by shell shock, or permanent invalids by inflammatory gases, smothered in masses by deadly gas, or made to die in epidemics whose irresistible germs are spread by airplane?

If we have another war, we may have no civilization left after it is over. The science of destruction was in its infancy during the World War. The progress in the art of destruction since 1918 has been swift and appalling. The World War was a baby in comparison to what applied science can make the next war.

Who won advantage by the last war? What nation is better because of it? There is but one answer. No nation is a better nation because of the World War. The universal result was wreckage, sorrow, and discontent, with satisfaction nowhere to be found.

It is the task of the higher citizenship to arrange the relations of the groups of people called nations so that war shall not happen again. What can we do to bring this thing to pass? I asked myself that question again and again, both during the war and after the armistice.

I was doubtless only one of millions who had the devastating experience of feeling the whole basis of things slip from under us as we saw no hope for civilization. Then, one morning in January, 1919, the light of hope returned to me. I was restored to membership in a progressive civilization, because I thought that I saw something reasonable enough to hope for and good enough to work for-something that might be a way out. My rebirth of hope ran like this. In the first years after the War all attempts at world organization will be bound by compromise. For some decades the plans for organization must be feeble, and they must undergo numerous changes. Sometimes it will seem that even the most promising plans can barely exist, much less make progress necessary for world peace. It seemed to me that twentyfive, perhaps even fifty, years would be required to demonstrate the success or failure of plans for peace and that the deciding factor would be the attitude of men's minds a quarter or a half century hence.

The attitude of mind that will make peace secure will be of slow development. Even wars do not happen suddenly. War is like fruit. The seed is planted, the tree grows and blooms, the fruit is set, and finally it comes along to ripeness. Will men's minds in twenty-five or fifty years ripen into sweet and nutritious fruit of peace or the bitter and poisonous fruit of war? The answer to that question depends largely upon America. The largest single factor in this world situation, this world of organization -this world of peace or this world of continuing anarchy and world war-will be the people of the United States. What they think and feel and do will almost settle it, as it did the World War. Then I saw that it was a problem of education, largely a school problem. Most of these people whose opinions are to decide the future are not yet in the schools, most of them indeed are not yet born.

Then came the question, what can I do to affect men's minds in this coming quarter century or half century of mind-making that will be so fateful for the world? 
For a little time I wished that I might again be a teacher of history, that I might write history text-books for the school children of America. Further thought showed me that history was not the most effective avenue. History as now organized in our schools deals with but a corner of the world; a few countries, our own country and its historic roots, leaving most of the world as much in the outer darkness as it appears on a map of the world made by the Romans.

It is through the geography book and the geography teacher that the child is introduced to his own country and also to the whole world with all its countries and all its peoples. The geography teacher has a great responsibility in introducing the child to his neighbors upon this earth. This task has two parts: to teach the facts of geography and to encourage an atitude of mind. The book carries the body of knowledge, but the teacher can give it its soul, helping the child to an attitude of mind.

As a body of knowledge, geography is undergoing swift advance. Not long ago it was a deadly memorizing rote of question and answer, with no more explanation than a multiplication table. Now each year sees a deepening realization that the science of geography is really a study of cause and effect, an explanation of things, a basis of understanding, a subject valuable in finance, manufacturing, and trade as well as in citizenship and in the higher citizenship. Not only is an understanding of geography a vital part of training for citizenship in any country, but it is the chief opportunity in our schools for teaching the higher citizenship-the relations, the good relations of the nations with each other as nations.

We teachers know that the children will forget most of the facts that we teach them about any subject which they do not continue to study. But we also know that even after many of the facts are gone, there is left a residue of understanding - of mental background-something of indispensable value well recognized in cultural education and even in training for business. After many of the facts of geography are gone from the mind that has studied about foreign countries, there will be certain spiritual residues; and here is the teacher's great opportunity to promote the higher citizenship. You can help the child, indeed, it is impossible that you shall do other than help the child toward respect or disrespect for other peoples, towards sympathy or antagonism, towards understanding or misunderstanding. In other words, we are bound whether we wish it or not to help toward peace and world organization or help toward misunderstanding and war.

\section{R E S P E C T, SYMPATHY, UNDERSTANDING- THESE ARE THE GREAT SPIRITUAL POSSI- BILITIES OF THE GEOGRAPHY CLASS \\ I. Respect}

To have world peace, peoples must learn to respect each other. We want to teach the children of America to be mentally polite to other nations just as we want them to be personally polite to their neighbors; then they will begin to respect other nations.

In making children acquainted with foreign peoples, we have an instinct to overcome, the herd instinct, the instinct for likeness as against unlikeness, the instinctive egotism which makes us feel that things different from our own are not so good as our own. We see a bit of this creeping out in the definition of the word "barbarian," which is nothing but Greek for "foreigner."

One of the greatest verses of Scripture tells us to judge not, that we be not judged. The geography class is a continual temptation to judge, and it is also a continual opportunity for the teacher to inculcate a piece of fundamental wisdom, namely, that difference does not necessarily mean inferiority or superiority. It is a difference for which there is a reason. Of course, the first instinct of the youngster is the instinct of superiority, which the skilful teacher will seek to modify with a dose of respect. 
The wide open road to teaching respect is furnished by the skill of foreign peoples. Look at the Eskimo's boat, made in some cases of skins sewed together with sinews and stretched around a framework of bones. In this skilfully made boat sits the lone paddler with his blouse of waterproof skin bound tightly around the opening of the boat, around his wrists and neck. If his boat upsets, no water can get into it. With a flip of his paddle he turns it upright and paddles on. This is one of the most marvelous marine creations of the human race. We have nothing that can rival it; and look at the materials of which it is made!

The examination of the Eskimo's tackle reveals case after case of skill quite beyond any hope of rivalry by the children in our schools.

Again, we come to the American Indian. Nearly every school is within reach at least of an Indian arrow head or pictures of Indian things. Could the children of the school or their parents make these Indian things? No. Shall we disrespect the Indian who is our superior in certain kinds of handicrafts or shall we esteem him as a master workman with abilities different from our own?

Take the Bushman of Australia. Perhaps it will be pointed out that he is one of the least intelligent of men, with the lowest social organization. But look at the boomerang. It is one of the most marvelous missiles in the world. Can any of our athletic boys throw a boomerang so that it will return to the thrower? Or can any of our intelligent ones identify tracks as the Bushman can?

Once the children's minds are directed in these channels, they realize that here (in some things) is their superior.

We can go on this way with all the various peoples of the world. Once the teacher has the theme, the great idea, the material is at hand or easily to be found for the inculcation of respect for the skill and for many other achievements-German science, French art, Chinese and Japanese art, the skill of the South American Indian who makes the Panama hat.

There is always the fact that the child cannot do these things, that their parents cannot do these things, and we must respect these people as our superiors in these particulars and therefore entitled to be looked upon without any concept of inferiority.

\section{Sympathy}

World peace depends upon sympathy between peoples. Antagonism leads to war.

The commonest basis of human relationships outside the family is the fellowship of common activity or interest. We get together as teachers, as spectators or players of baseball, cards or golf, as breeders of bulldogs, chickens, as members of sewing societies, engineering societies, horticultural societies, labor unions, manufacturers' associations, etc., etc.

One of the great facts for the teacher of geography is the study of peoples, as people engaged in the same jobs as ourselves. Men are everywhere making a living, making a home, educating their children, making a neighborhood and a government. In these fundamental activities we are like the Eskimo, the Bushman, the Indian, the Frenchman, the German, the Englishman, and the South American Indian. We are all fellow craftsmen, and it is thrilling to discover these facts.

Take the simple matter of food. All the world is a great group of fellow craftsmen who are engaged upon the endless task of feeding themselves, and the geography class gives continual opportunity for comparing the work of these differing craftsmen as they seek and achieve this common end in so many different kinds of places.

The farmer in Colorado or Minnesota or Maine or Ireland or Germany or Russia digs potatoes. This is the same kind of thing as the native of the tropic forest country does who digs cassava roots or 
sweet potatoes or yams or cultivates his bananas.

The farmer with his reaper is engaged in the same task as is the Hindu or the Chinese or Japanese or Filipino who wades about his rice paddy, planting and weeding his rice. The aim of all is to supply grain for hungry populations.

We have the same chance to create interest and sympathy in studying about the clothes, food, shelter, and tools of all mankind. So also with their governments. This is a particularly good opportunity to show that perhaps our government may be better than theirs, but in the next breath we ought to point out where our own might be improved. Thus the child will gradually get the realization that his country is a country which may change for the bettera country of progress. No child should be allowed to think of government as finished. $\mathrm{He}$ may love his country best, but if his love takes the attitude of undue superiority over other countries, he becomes cocky and a trouble-maker. To realize the fact that one's government is still capable of improvement tends to develop sympathy with other peoples in this the most difficult of all human tasks-government, the creation of society.

The comparison of the craftsmen and of the day's work in our own country and foreign countries will lead almost inevitably to the realization-indeed to the proof-that our opportunities for making a living are better than theirs. This explains the desire of the foreigners to move to this country and brings up the question of immigration.

In this concept lies again the essence of sympathy rather than of antagonism. Incidentally, also, it places upon us the necessity of vast good manners to keep antagonism out of the hearts of the poorer ones who are shut out of this rich Eden.

\section{Understanding}

For world peace we must have understanding. Prejudice leads to war.
One night my neighbor who likes to call himself a "one-hundred-per-cent American" walking up the street with me from a lecture about a foreign country remarked, "Yes, but those foreigners do such foolish things." That is the stuff of which war is made. The foreigners do not do such foolish things. They do such natural things, as we can see if we really understand them, their position, and their problems. The great spiritual and mental test for success in the teaching of geography is the creation of understanding. We present to the child the fact that a foreign people is different from ourselves. What is his first reaction? Does he without understanding judge it and dismiss it with a bad name as Wop, Dago, Guinea, Greaser, or some such? Or does he desire to understand why they are different?

It is easy to see reasons why the Eskimo's house is of skin or snow, why the mountaineer's house is of wood, that of the desert of sun dried brick, that in the tropic forest of grass and thatch, of the city of burned brick, and that of Italy of stone. It is equally true that the foreigner has done what he has done for what seems to him to be a good reason, and it is probably true that if we had been in his position we would have done as he has done. Were not our ancestors primitive people living in the woods in a way that we often call "savage" but a short time ago as history runs. We believed in witches but day before yesterday as history counts time. We have changed from this condition chiefly through the discovery of new knowledge, which in turn has brought us better opportunities. One of the interesting things of the world is the speed with which other peoples change also when new knowledge and new opportunities come to them.

If we know enough geography and enough history and enough human nature, we shall find that the foreigner is neither queer nor foolish, but that he has done very 
much as we would have done under the same circumstances.

We teachers of geography know that the names of capes and mountains will fade from the student's mind, that many of the rivers and capitals will melt into an indistinct haze-that many, perhaps most of the facts will be gone from our students when, at thirty-five or fifty-five years of age they turn their minds into the resistless sea of public opinion and their votes into the ballot box that decides some world crisis. We, the teachers of geography, should realize that the frequently recurring opportunities of the geography class means this-that to us more than to all other social agencies combined, is given the power to decide whether the future act of the voter shall be an act of respect or disrespect, of sympathy or antagonism, of understanding or ignorant prejudice-whether war shall wreck us all or whether we shall put it into the limbo where now the personal duel residesburied by a better method. Now that a better way is established the gentleman finds that he can get along perfectly well without puncturing his fellowman with a rapier or a bullet.

This opportunity of the geography teacher is made even greater than it seems by the fact that most adult activities are bent toward the realization of desires conceived before the age of fifteen years.

\section{J. Russell Smith}

A university residence hall is neither a rabbit warren, a barracks, nor a boardinghouse. It is a center of college and university life and influence, where no inconsiderable part of the student's education is to be gained by contact with fellow-students and where he contributes to and shares in that college life and college spirit which, however elusive and difficult to define, are powerful factors in fashioning the mind and character of the American college student -Nicholas Murray Butler
SHOULD THE BLUE RIDGE MOUNTAINS BE MADE A NATIONAL PARK

A SOCIAL SCIENCE PROBLEM FOR THE JUNIOR HIGH SCHOOL

$\mathrm{T}$ RAINING for citizenship is the general aim of the social studies which have become the backbone of the curriculum as a result of the nation-wide survey by Dr. Edgar Dawson and individual investigators. Such abilities, inclinations, and ideals as will enable the youth to take his place in a rapidly changing society must be developed. He must be trained to attack a problem, investigate and organize evidence, and to withhold judgment until all evidence is collected; he should be able to trace the effects of past events upon social living today; he should realize the growing interdependence of all countries; he should understand major contemporary problems and his part in solving them. ${ }^{1}$

A heavy responsibility rests upon the teacher to choose such problems as will carry out this aim. After choosing the problem she must find a means to arouse interest in it. A good scheme for doing this is to make a local problem the point of contact. As an example of this I shall consider the problem of conservation. Experts tell us that our coal supply may not last one hundred years, that our oil may not last fifty years, and that a million square miles of timber have been cut down and not replaced. This is a problem of national interest that should be given careful study.

In looking for a local approach to this problem the teacher will find that the newspapers are a great aid. Virginia newspapers are now featuring the fight waged in Congress to put a national park in the Blue Ridge Mountain. The valley people are enthusiastic over it; the mountain people want to retain their homes. But other sections,

1. Report of Committee on social studies in the junior high school. 